\title{
Application of the Neo Vernacular Theme in the Redesign of Banjar Nyuh Port in Nusa Penida, Bali
}

\author{
I Gede Dede Meirianta ${ }^{1}$, I Nyoman Widya Paramadhyaksa ${ }^{2}$, I Ketut Mudra ${ }^{3}$ \\ Bachelor Degree of Architecture Study Program \\ Faculty of Engineering-Udayana University \\ Jimbaran \\ dmeirianta@gmail.com \\ Architecture Study Program \\ Faculty of Engineering-Udayana University \\ Jimbaran \\ Architecture Study Program \\ Faculty of Engineering-Udayana University \\ Jimbaran
}

\begin{abstract}
Nusa Penida is one of the islands in Klungkung Regency, Bali, which is currently growing rapidly. This can be seen from the increasing number of tourists every year. Based on the data of the number of people who visited Nusa Penida, it could be seen to have an increase in the need to provide adequate facilities of the port. Banjar Nyuh Port is one of the ports in Nusa Penida which currently needs to be redesigned in order to facilitate sea transportation activities. Re-design is a process of replanning a facility in an effort to improve the functions that are contained and create better conditions than before. The Redesign of the Banjar Nyuh Port aim to optimize the port function through solving the problems encountered using innovative thinking in redesigning. In the process of redesign based on a theme as the basis, the theme used must be in accordance with the context of the problems, location, culture and social of the local community so that the appropriate theme is to apply the Neo Vernacular Architecture theme to the design. The applica-tion of Neo Vernacular Theme can display the traditional impression of Balinese Architecture combined with the value of modern architecture so as to create a design that contains cultural traditions and design innovation in it.
\end{abstract}

Index Terms - redesign, port, neo vernacular, nusa penida.

\section{INTRODUCTION}

The port is one of the places in activities related to sea transportation activities. The Banjar Nyuh Port, located in Banjar Nyuh, Ped Village, Nusa Penida, has been operating since the 1970s by serving the Nusa Penida-Sanur crossing route, Bali. The crossing ships that depart or depart through this port have various destinations, such as service, shipping, crossing services, and tours. The crossing routes also began to vary, such as Nusa Penida-Sanur, Nusa Penida-Serangan, and Nusa Penida-Padang Bai. The increase in tourists to visit Nusa Penida through the Banjar Nyuh Port needs to be balanced with more adequate facilities and infrastructure to accommodate activities in the port, based on this, a redesign is carried out at the Banjar Nyuh Port.

In the process of redesigning the Banjar Nyuh Port, the theme of Neo Vernacular Architecture was chosen as the initial basis of design thinking. In determining this theme there are a number of things that are applied, such as site zoning, building appearance, material and color. This will affect the space, shape, and also the psychic community. In essence, the principles of Neo Vernacular Architecture were developed based on a blend of traditional architecture and modern architecture. The application of Neo Vernacular Architecture style to buildings is expected to be able to 
maximize cultural traditions and modern design innovations in it.

\section{RESUlt AND ANALISYS}

\section{A. Zoning and Facade}

Banjar Nyuh Port in Nusa Penida is one of the places of various sea transportation activities in Nusa Penida. Increasing the number of tourists and the lack of facilities in the Banjar Nyuh Port building is the starting point of the redesign of the port. With the basic idea of design using Neo Vernacular Architecture, it is expected that port facilities have the characteristics of traditional architecture and modern architecture. The facilities that complement the sea transportation activities at the Banjar Nyuh Port include management offices, control towers, buildings intended for passengers, parking, and cafetaria, so that the facilities provided at the Banjar Nyuh Port can provide comfort for passengers and the public around the port so that it has a positive impact on the economy of the people in Nusa Penida.

\section{B. Theme}

The theme applied in the redesign of the Banjar Nyuh Port in Nusa Penida is Neo Vernacular Architecture. The Neo Veracular Architecture Theme is an updated architectural style of modern architecture, presenting local architecture combined with a more modern form. This theme will later apply the traditional Balinese concept, namely the concept of zoning, to facilitate circulation in the site. The application of Tri Angga's conception in the appearance of the building which requires the building to have elements of head, body, and legs. The material used uses local materials that are easily available in Bali, especially in Nusa Penida.

\section{Sirculation}

In the zoning system, the concept of zoning is applied, which is related to the theme to improve circulation within the site. Site zoning is divided according to zones, namely the public zone, semi-public zone, and private zone[1]. In the public zone is placed a parking lot, a building for passengers, and cafetaria with consideration that the building functions as a commercial building. The semi-public zone is housed by a management building and a watchtower dedicated only to port employees. The private zone is placed in the sacred area by applying the direction of the main compass, namely north (kaja) and east (kangin).
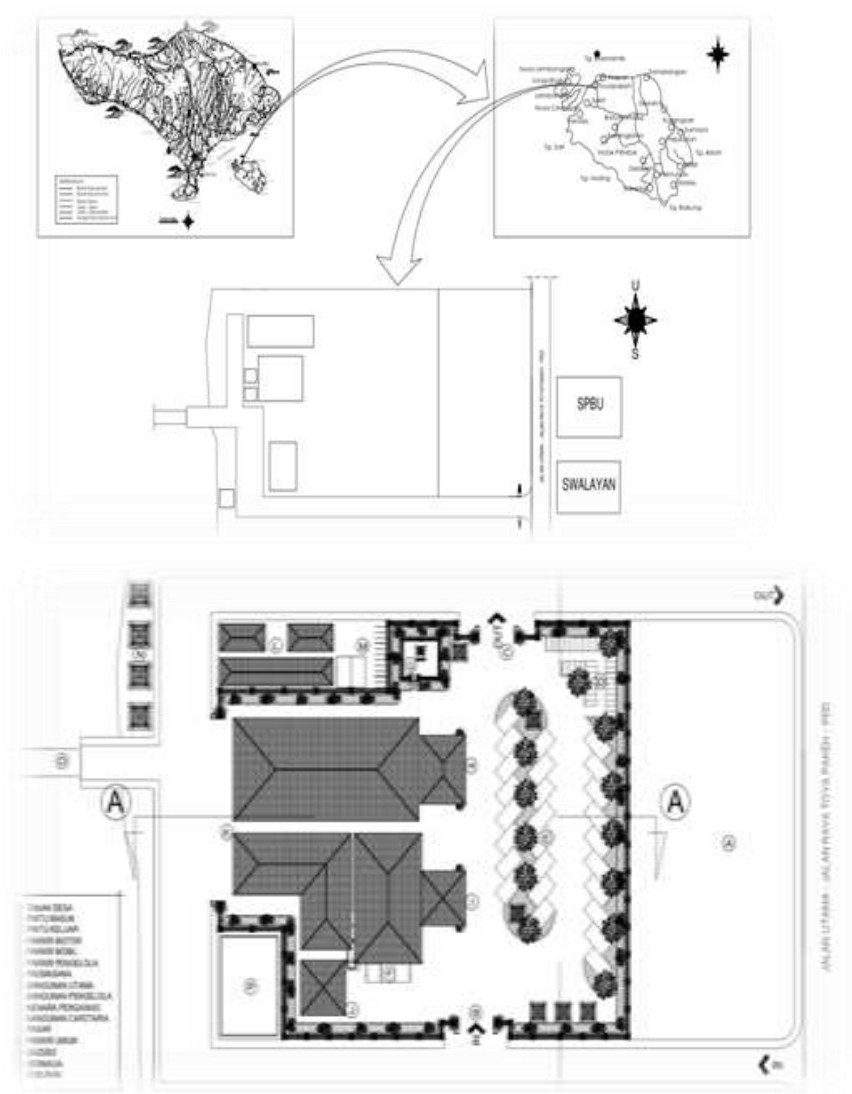

Fig. 1. Zoning of Port (source: Meririanta)

\section{Elevation}

In the redesign of the Banjar Nyuh Port, the appearance of the building was adjusted to the Neo Vernacular Architecture theme in the form of the Tri Angga conception. This concept divides the three spatial concepts including the head (main intermediate) as the roof, the body (intermediate angga) as a wall, and the foot (nista angga) as the floor. The application of the Tri Angga conception at the Banjar Nyuh Port is found in all four buildings. The entire building uses a roof covering as a head using tiles, application of brick material on the wall as a building body and ceramics and wood of different sizes and types in each building as feet. There are several pillars with Balinese carvings that have been simplified because the buildings are commercial in nature and add to the impression of local architecture which is an attraction so that the community is interested in visiting and feel the aesthetics of the building's appearance.

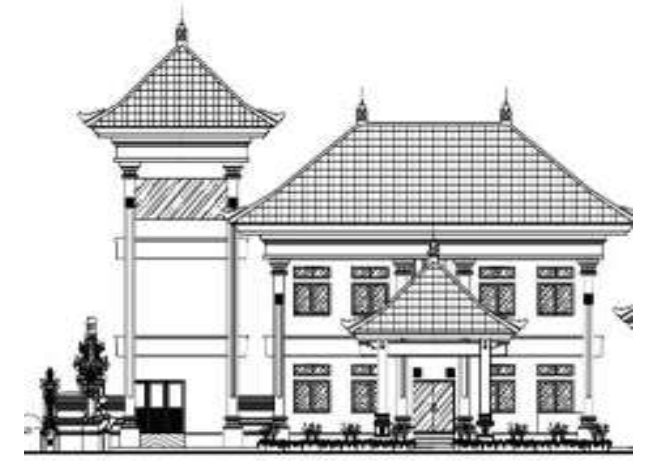




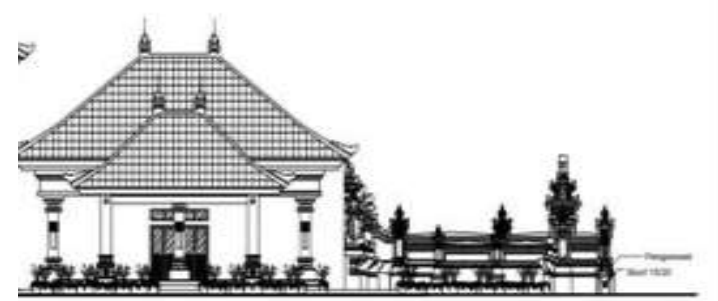

Fig. 2. Front Elevation (source: Meririanta)

In the entrance view using the temple briefly to give the impression of inviting by using sandstone material. Hardscape elements in outdoor spaces use grassblock material, paving and garden lighting, softscape in outdoor spaces uses ketapang trees as a shade in parking areas, palm trees, kalatea banana trees, and ornamental plants.

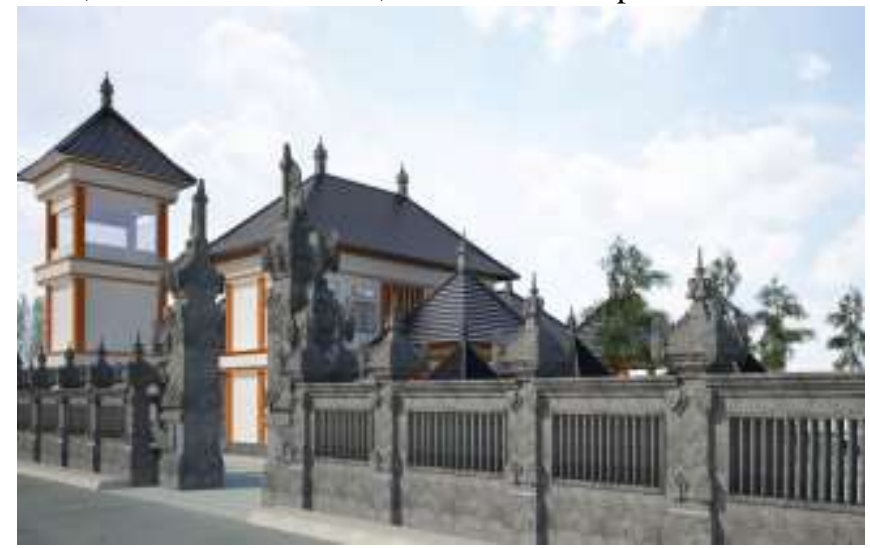

Fig. 3. Entrance Elevation (source: Meririanta)

\section{E. Materials}

The building materials used at the Banjar Nyuh Port use local materials which can be found in Bali, especially in Nusa Penida. For example in the use of roofing material, using clay tiles that are easily available in Nusa Penida and Bali. On the walls using red brick and white brick typical of Nusa Penida. The floor of the building uses attractive wood and wood material. Determination of the basic color of the building using a white base color.

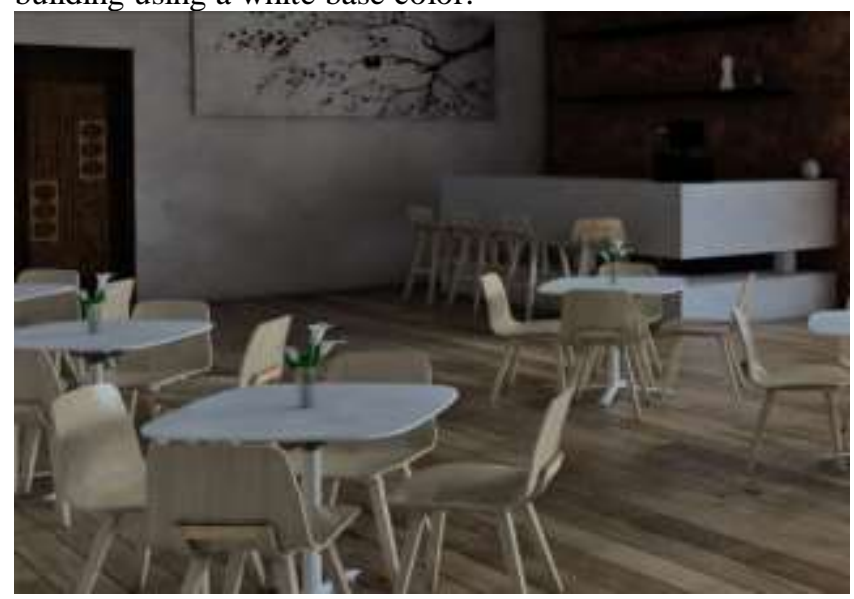

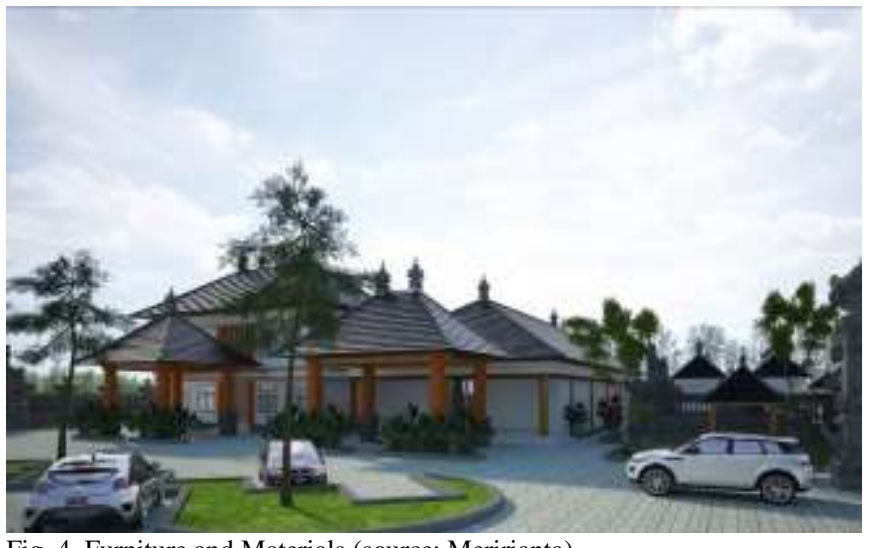

Fig. 4. Furniture and Materials (source: Meririanta)

\section{CONCLUSION}

Banjar Nyuh Port in Nusa Penida is one of the places for sea transportation activities with building facilities for passengers, management buildings, control towers and cafeterias. The redesign of the Banjar Nyuh Port uses the theme of Neo Vernacular Architecture in the form of zoning concept on the site zoning as the center of orientation and circulation. The appearance of the building also uses the Tri Angga conception whose application to the building is the presence of elements of the head, body, and legs. The head element is on the roof of the building, the body is on the wall of the building, and the foot is on the building floor In material and color using red bricks that adopt Balinese architecture. The re-planning of the Banjar Nyuh Port was designed with the aim of increasing the complete facilities to the community who wanted to carry out sea transportation activities.

\section{REFERENCES}

[1] Darmasetiawan, Christian, Lestari Puspakesuma, "Teknik Pencahayaan dan Tata Letak Lampu Jilid 1 Pengetahuan Dasar", Jakarta: PT. Gramedia Widiasarana Indonesia, 1991. 